\title{
Georgeantha hexandra, a new genus and species of Ecdeiocoleaceae (Poales) from Western Australia
}

\author{
Barbara G. Briggs and L.A.S. Johnson ${ }^{\dagger}$
}

\begin{abstract}
Briggs, Barbara G. and Johnson, L.A.S. (Royal Botanic Gardens, Mrs Macquaries Road, Sydney, NSW 2000, Australia) 1998. Georgeantha hexandra, a new genus and species of Ecdeiocoleaceae (Poales) from Western Australia. Telopea 7(4): 307-312. The genus Georgeantha and its single species are described. G. hexandra is a rare species of sandplains in the Jurien-Eneabba region north of Perth in the southwest of Western Australia. Brief comment is included on culm anatomy, flavonoids and DNA findings, in addition to the exomorphological features distinguishing this from Ecdeiocolea, the only other genus of the Ecdeiocoleaceae.
\end{abstract}

\section{Introduction}

This paper validates the name of this new genus in advance of the treatment of Ecdeiocoleaceae in The Families and Genera of Flowering Plants, edited by K. Kubitzki (Linder, Briggs \& Johnson in press), in Meney \& Pete (in press), and in the Flora of Australia (Briggs, Johnson, Porter \& Krauss in preparation). The Ecdeiocoleaceae, Restionaceae and some related families are also currently the subject of flavonoid analysis by Harborne, Williams and Greenham (Williams et al. 1997 \& in press) as well as investigation by DNA sequencing of $r b c \mathrm{~L}$ and the $t r n \mathrm{~L}$ intron (Briggs, Marchant, Gilmore \& Porter, unpublished results).

Features of Georgeantha were previously reported under the unpublished name 'Georgiella' (e.g. by Williams et al. 1997, Meney et al. 1997, Roche et al. 1997), but the latter name is unavailable, being preoccupied by a member of the Rhodophyceae.

Georgeantha B.G. Briggs \& L.A.S. Johnson, gen. nov.

$\mathrm{Ab}$ Ecdeiocolea combinatione characterum sequentium distinguitur: habitus rhizomatosus, rhizomatibus basibusque culmorum villosis; vaginae spiculaeque aliquot per culmum, vaginis culmi caducis; tepala staminaque 6; loculi stylique 3; fructus capsulares; chlorenchyma costis sclerenchymatis tenuibus divisum.

Type species: Georgeantha hexandra B.G. Briggs \& L.A.S. Johnson.

Monoecious, rhizomatous. Rhizomes villous, largely covered by almost glabrous cataphylls. Culms terete, striate. Sheaths: basal sheaths persistent, striate, lamina reduced; lower culm sheaths caducous, the nodes swollen and prominent. Inflorescence of two or few spikelets. Spikelets: axis with long pale branched hairs; glumes all fertile, either male or female flowers at the spikelet base, flower sex alternating once or twice towards the apex depending on spikelet size. Flowers: male and female flowers similar; tepals 6, outer tepals keeled, the abaxial outer tepal and inner tepals \pm flat. Male flowers: stamens 6, free; anthers 2-locular, 4-sporangiate, versatile, latrorse, dehiscing by two longitudinal slits; pistillode present. Female flowers: staminodes minute; ovary 3-locular; styles 3, free, stout, wholly stigmatic, densely covered adaxially with long stigmatic branches. Fruit a loculicidal capsule. Seeds patterned with convex, strongly lobed cells.

† Deceased 1 August 1997. 
Culm anatomy: with deep narrow grooves extending halfway to base of chlorenchyma, stomates and accompanying sclereids at base of grooves, ridges with a central sclerenchyma rib 1-3 cells wide extending outwards from the parenchyma around the outer bundles to the sclerenchyma cap (Fig. 1). The flavonoids of Georgeantha and Ecdeiocolea are clearly distinct (Williams et al. 1997), G. hexandra containing quercetin and galactose which are absent from E. monostachya, whereas both genera contain isorhamnetin. Georgeantha and Ecdeiocolea are closely associated in analyses of genetic sequence data of DNA from $r b c \mathrm{~L}$ and the $t r n \mathrm{~L}$ intron (Briggs, Marchant, Gilmore \& Porter, unpublished results).

The name commemorates Alex George, a notable Australian botanist, expert in the flora of Western Australia and for some years Executive Editor of the Flora of Australia, who discovered this taxon and kindly drew it to our attention.

Distinguished from Ecdeiocolea by the rhizomatous habit (so that plants form widelyspaced clumps of culms over an area up to $50 \mathrm{~cm}$ across), villous rhizome and culm bases, the culms consisting of several internodes, prominent scars left by the caducous culm sheaths, inflorescence of 2-3 spikelets, trimerous flowers with tepals and stamens 6, trilocular ovary with 3 styles, fruit a capsule, and sclerenchyma ribs extending through the chlorenchyma to the sub-epidermal sclerenchyma. The contrasting features of Ecdeiocolea are: caespitose habit with large dense tussocks, rhizome and culms glabrous, culms consisting of a single long internode with 1 or 2 persistent sheaths high on the culm, spikelet solitary, flowers 2-merous with tepals and stamens 4, unilocular ovary with 2 styles, fruit a nut, and the lack of sclerenchyma ribs extending through the chlorenchyma to the sub-epidermal sclerenchyma.

A monotypic genus endemic in Western Australia.

Georgeantha hexandra B.G. Briggs E L.A.S. Johnson, sp. nov.

Type: Western Australia: $8 \mathrm{~km}$ NNW of Jurien Road on Cockleshell Gully road, 30¹1'30"S 11508'E, B. Briggs 7461 E L.A.S. Johnson, 29 Sep 1984 (holo NSW; iso B, BRI, CANB, K, MEL, MO, NBG, NY, PERTH).

Culmi 50-80 cm longi, 3- vel 4-nodis; spiculae 1.2-1.7 cm longae.

Rhizome horizontal, stout, 7-10 mm diam., densely villous with white hairs $6-10 \mathrm{~mm}$ long, partially covered by scarious cataphylls; the cataphylls pale brown, glossy, glabrous except for long hairs at the base and rarely distally on the keel, broadly ovate to deltoid but split along median line by sympodial growth of rhizome. Culms closely spaced, mostly 5(-8) $\mathrm{mm}$ apart on the rhizome, erect, 50-80 cm long, 1-1.5 mm diam., grey-green, internodes 4 or 5 , the lowest internode and base of the second internode densely woolly with white hairs up to $3.5 \mathrm{~mm}$ long. Culm sheaths: the 2 or 3 uppermost sheaths persistent, often crowded below the uppermost elongated internode; (2.2-) $4.5-7.0 \mathrm{~cm}$ long, green or straw coloured, glabrous, auriculate with a narrow membranous margin; lamina subulate, (1-)4-5(-9) $\mathrm{mm}$ long. Inflorescence branches slender, $1-2 \mathrm{~cm}$ long. Spikelets ovoid, $1.2-1.7 \mathrm{~cm}$ long, $0.5-1 \mathrm{~cm}$ wide; axis sinuous; glumes 8-12, ovate to broad-lanceolate, 4-8 mm long, dark-brown to black, concave, rigid, acute to acuminate, densely pubescent; margins broad, hyaline. Male flowers: tepals lanceolate, dark-brown, soft, densely pubescent adaxially toward the apex with pale hairs, acute, 5.5-7.5 mm long; filaments 3-7 mm long; anthers 2.5-3.5 mm long, attached slightly above the middle to the short connective. Female flowers: tepals lanceolate, acute, concave, dark brown with pale hyaline margins; pubescent toward the apex with pale, tangled, branched, multicellular hairs; outer tepals keeled, c. $5 \mathrm{~mm}$ long; inner tepals almost flat, 6-6.5 mm long. Capsule 3.5-4.0 mm long, brown, smooth, the valve margins prominently thickened and pale, often 1 or 2 carpels aborted. Seeds broad-ellipsoidal, c. $1.5-2.0 \mathrm{~mm}$ long. Chromosome number: $2 n=$ c. 64-66 (Briggs unpublished; voucher: Gittins 1710b) (Fig. 2). 

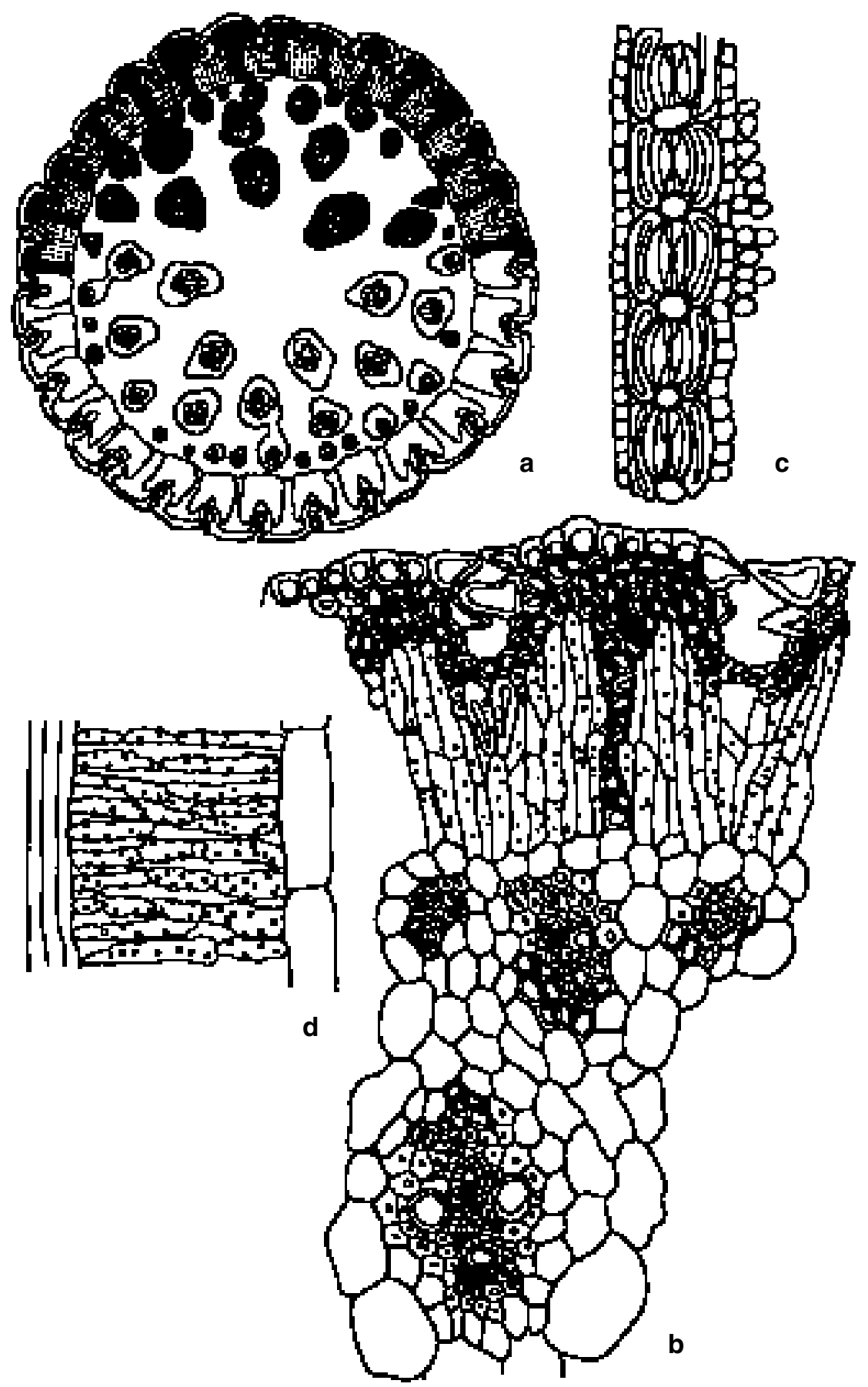

Fig. 1. Georgeantha hexandra, culm anatomy. a, transverse section showing sclerenchyma ribs and deep crypts (sclerenchyma indicated in black; chlorenchyma stippled). $\mathbf{b}$, detail of T.S., note the enlarged, overarching epidermal cells at entrance to crypts and stomates and sclereids at base. c, tangential longitudinal section showing row of stomates at base of crypt. d, radial longitudinal section of chlorenchyma showing peg cells in horizontal plates. (From Gittins 1710b.) Magnifications: $\mathrm{a} \times 45 ; \mathrm{b}-\mathrm{d} \times 240$. 


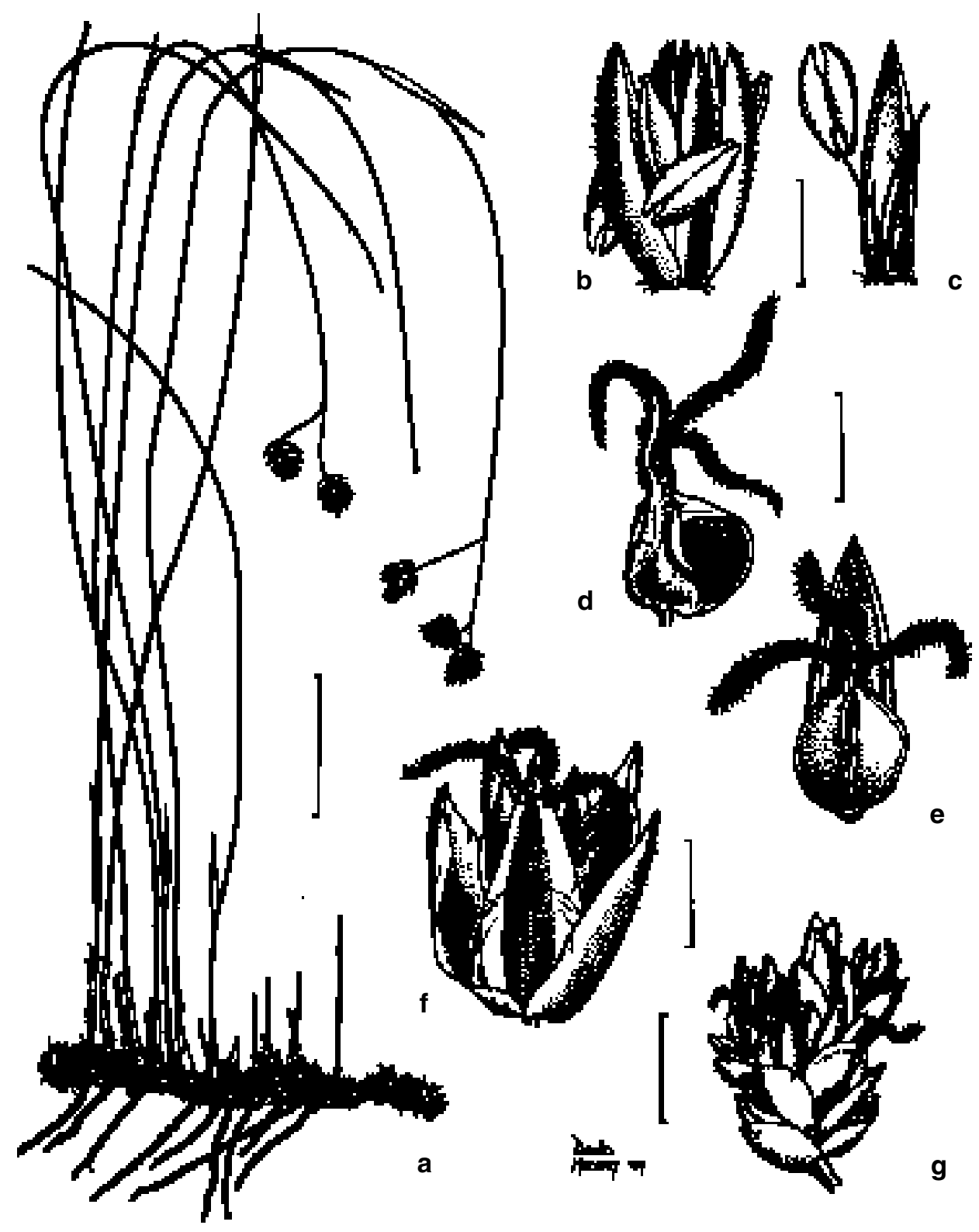

Fig. 2. Georgeantha hexandra. a, habit. b, male flower. c, dissected male flower. $\mathbf{d}$, fruit with seed. e, f, female flower. g, spikelet. a-c, from Briggs 7461; d, Briggs 6395; e, Gittins 17 106; f, Haegi 1911. Scale bars: $\mathrm{a}=5 \mathrm{~cm}, \mathrm{~b}-\mathrm{f}=3 \mathrm{~mm}, \mathrm{~g}=6 \mathrm{~mm}$. 
The epithet is from the Greek hexa, six, and -andrus, male, referring to the six stamens in the flower.

Distribution: in the Jurien-Eneabba region north of Perth in the west of Western Australia, in seasonally moist sites in tall shrubland or low heath on deep moist sand in a region of low rainfall. Resprouts after fire (Pate, Meney \& Dixon 1991, as 'Ecdeiocolea georgei'; Meney, Dixon \& Pate 1997, as 'Georgiella hexandra').

Conservation status: rare but not currently under threat (Meney et al. in press), Western Australian CALM Conservation Code P4, proposed ROTAP Code 2RCa.

Selected specimens examined: Western Australia: Irwin: $5 \mathrm{~km} \mathrm{~S}$ of Mineral Sands minesite, Eneabba, Meney 3090, 20 Dec 1990 (voucher for DNA sample, grown from tissue culture from wild source, NSW); c. 8 km S of Eneabba, Hnatiuk 771147, 17 Sep 1977 (PERTH, NSW); Brand Hwy, 13.5 km S of Eneabba at S boundary of Carnamah Shire, Briggs 6395, 27 Sep 1976 (NSW, PERTH); Stockyard Ck crossing, c. $22 \mathrm{~km}$ E of Green Head on road to Brand Hwy, Haegi 1911, 1 Nov 1979 (NSW, BRI, CANB, K, PERTH, RSA), 1912 (NSW, BRI, CBG, PERTH, RSA); 1 km W of Brand Highway on Jurien road, Wilson 2684, 2 Oct 1979 (NSW); 0.6 km N of Cockleshell Gully, W of Mt Peron, Briggs 6347, 26 Sep 1976 (NSW, MEL, PERTH), 6348 (NSW, AD, MO, RSA); Cockleshell Gully, Briggs 9016, 8 Oct 1992 (NSW, KPBG); near Mt Lesueur, Gittins 1710b, Sep 1976 (NSW); W of Coomallo Ck., E of Jurien, Griffin 2704, 2716, 2717, 24 July 1980 (PERTH); c. 6 km W of Mt Lesueur, George 14599, 17 June 1977 (PERTH).

\section{Acknowledgments}

Many people assisted in this study and related work on Restionaceae over the years. Thanks go especially to Carolyn Porter, Siegfried Krauss, Anna-Louise Quirico, Barbara Wiecek and Kate Green, also to Lesley Elkan and David Mackay for the illustrations. Peter Wilson assisted greatly with the Latin diagnoses and nomenclature. The opportunity to examine specimens on loan or in other herbaria assisted the work. Cooperation and joint fieldwork with John Pate and Kathy Meney gave information and valuable insights, as did associated DNA sequencing studies by Adam Marchant, Simon Gilmore and Carolyn Porter and investigations of flavonoids by Christine Williams and Jeffrey Harborne. Grants from the Australian Research Council and Australian Biological Resources Study provided valuable technical help and supported field studies.

\section{References}

Linder, H.P., Briggs, B.G. \& Johnson, L.A.S. (in press) Ecdeiocoleaceae. In K. Kubitzki (ed.), The Families and Genera of Flowering Plants. (Springer-Verlag: Berlin)

Meney, K.A., Dixon, K.W. \& Pate, J.S. (1997) Reproductive potential of obligate seeder and resprouter herbaceous perennial monocots (Restionaceae, Anarthriaceae, Ecdeiocoleaceae) from south-western Western Australia. Austral. J. Bot. 45: 771-782.

Meney, K.A. \& Pate, J.S. (in press) Australian Rushes - Biology, Identification and Conservation of Restionaceae and Allied Families. (University of Western Australia Press: Perth).

Meney, K.A., Pate, J.S., Dixon, K.W., Briggs, B.G. \& Johnson, L.A.S. (in press) Conservation of Australian Restionaceae. In K.A. Meney \& J.S. Pate (eds), Australian Rushes - Biology, Identification and Conservation of Restionaceae and Allied Families. (University of Western Australia Press: Perth).

Pate, J. S., Meney, K. A. \& Dixon, K. W. (1991) Contrasting growth and morphological characteristics of fire-sensitive (obligate seeder) and fire-resistant (resprouter) species of Restionaceae (S. Hemisphere restiads) from south-western Australia. Austral. J. Bot. 39: 505-525.

Roche, S., Dixon, K.W. \& Pate, J.S. (1997) Seed aging and smoke: partner cues in the amelioration of seed dormancy in selected Australian native species. Austral. J. Bot. 45: 783-815. 
Williams, C.A., Harborne, J.B., Greenham, J., Briggs, B.G. \& Johnson, L.A.S. (1997) Flavonoid evidence and the classification of the Anarthriaceae within the Poales. Phytochemistry 45: 1189-1196. Williams, C.A., Harborne, J.B., Greenham, J., Briggs, B.G. \& Johnson, L.A.S. (in press) Flavonoid patterns and the revised classification of Australian Restionaceae. Phytochemistry.

Manuscript received 8 December 1997

Manuscript accepted 26 February 1998 